\title{
The Market as an Object of Attachment: Exploring Postsocial Relations in Financial Markets ${ }^{1}$
}

\author{
Karin Knorr Cetina \\ Urs Bruegger
}

\begin{abstract}
This paper rests on the assumption of an increased presence and relevance of object worlds in the social world. It holds that this influx of object worlds coincides with changing patterns of human relatedness that can be glossed by the notion postsocial forms. Postsocial forms include object-relationships where the objects are non-human entities. One characteristic of the present situation is that perhaps for the first time in recent history it appears unclear whether other persons are, for human beings, the most fascinating part of their environment. Objects may also be the risk winners of the relationship risks which many authors find inherent in contemporary human relations. Postsocial forms "step into the place" of social relations where these empty out, where they lose some of the meaningfulness they have had in earlier periods. A condition for understanding this role of objects is that we develop, in social theory, adequate concepts of objects that break with the tradition of seeing them merely as abstract technologies that promote alienation or as fetishized commodities that freeze and numb any human or political potential (Marx). In this paper, we use a different conception developed in an earlier paper. We also explore in some detail a notion of postsocial relatedness that is based on the idea of a dynamic of wantings and lacks of fulfilment. The paper explores this framework in the area of financial markets, where traders relate to the market as an object of attachment within an environment of reiterated lacks.
\end{abstract}

1. An earlier version of this paper was presented at the conference "The Status of the Object in Social Science," Brunel University, Uxbridge, UK, 9-11th September 1999, where we received a number of helpful comments and suggestions. We are indebted to Nico Stehr for his useful commentary. Our greatest debts lie with the managers, traders, salespersons, and analysts at the global investment bank whose activities we studied, and who so generously shared with us the information we collected. 
Résumé: Les auteurs constatent la présence et l'importance grandissantes de mondes d'objets au sein de l'univers social — afflux qui refléterait une transformation des rapports humains, exprimée par la notion de "formes postsociales ». Ces formes incluent des relations objectales au sein desquelles l'objet désigne une entité matérielle (c.-à-d. non humaine). Pour la première fois, dans l'histoire récente tout du moins, les autres êtres humains ne sont peut-être plus les éléments les plus fascinants de notre univers. Les objets seraient le pari gagnant d'un modèle de factorisation des risques inhérents aux relations humaines que relèvent de nombreux chercheurs. Les formes dites postsociales s'instaurent quand les relations sociales se vident du sens qu'elles avaient jusqu'alors. Pour mieux comprendre ce phénomène, il est impératif de repenser les concepts traditionnels, qui voient les objets comme des technologies abstraites aliénantes ou des commodités fétichisées, obnubilant tout potentiel humain ou politique (Marx). Nous développons ici un concept différent, ébauché dans une étude antérieure. Nous explorons également la notion de rapports postsociaux d'après une dynamique de désirs et de besoins inassouvis - notamment dans l'univers boursier, où les agents entretiennent avec le marché des relations objectales fondées sur des manques réitérés.

\section{Introduction}

This paper is based on an earlier one which developed an analysis of an "object-centred sociality" as a possible social form - a form constituting something - like the reverse side of the contemporary experience of individualization (Knorr Cetina, 1997). The argument has been that the current understanding of the "disembedding" of modern selves in contemporary posttraditional societies ignores the expansion of object-centred environments which situate and stabilize selves, define individual identities just as much as communities or families used to do, and promote forms of sociality that feed on and supplement the forms of sociality studied by social scientists. Our general take on the desocializing forces and experiences of current transitions is that they need to be confronted with a postsocial model of sociality: one that brings into view objects as the risk winners of the relationship risks which many authors find inherent in contemporary human relations, and object-relations as a category of relationships that are perhaps increasingly competing with human relations. One distinctive characteristic of the contemporary scenario could be that perhaps for the first time in recent history it appears unclear whether, for individuals, other persons are indeed the most fascinating part of their environment - the part we are most responsive to and devote most attention to (see also Turkle, 1995). With the idea of "postsocial relations" we attempt to take this possibility seriously and to soften some boundaries that have been made rigid by previous approaches.

The notion "postsocial" simply serves as a convenient gloss on an open range of cultural forms which transcend common definitions of the social order but which are manifest today in a variety of settings. These forms include high risk behavior in relation to natural environments of the sort described by Lyng (1990; the example is skydiving); definitions of identity in terms of object principles and categories which emerge from the analysis of 
consumer behavior and shopping malls (e.g. Falk and Campbell, 1997; Ritzer, 1999); and the kind of attachments described in this paper. What these forms have in common is that they involve "object-relations" with non-human things which challenge and to some degree replace human relations. But postsocial analysis can also be brought to bear on human relations where these depart from our core notions of sociality. Potential for such analyses can be found in collective disembodied systems generated in a symbolic space, for example forms of human interaction mediated by and constituted through communication technologies. We may call these postsocial forms since they arise in circumstances where interaction, space, and even communication appear to mean something different from our accustomed understanding of the terms. How the characteristics of social interaction change when the technological is the natural, and the "social space is a computer code, consensual and hallucinatory" (Stone, 1996: 38) is an open question that needs to be answered by empirical studies. In what follows, we will not explore this question but rather focus on postsocial relations in an area where the object is both human and non-human: our object of illustration will be "the market," our data derive from an area which increasingly defines contemporary life, that of financial markets. We will refer to the market as an object in accordance with traders' way of seeing it as the aggregate of largely anonymous behavior and come back to the human component of the market later in this paper.

The argument we make is, in a limited sense, historical: it rests on the assumption of an increased presence, relevance, and recognition of particular categories of things and of their attendant environments in contemporary life. The "influx" of object-worlds into the social world, their persistent flow and requirements can be glossed from the recent bodies of literature devoted to them: examples are the literature on information and communication technologies (Turkle, 1995; Heim, 1993), on the return of "nature" and the demands of the natural environment (Sheldrake, 1991; Serres, 1990), on consumer objects (Baudrillard, 1996; Ritzer, 1999; Miller, 1994), and on financial markets (e.g. Smith, 1981; White, 1981; Baker, 1984; Abolafia, 1996). The "influx" of object worlds coincides with changing patterns of interpersonal and community relations which have been documented and discussed by Lasch (1978), Coleman (1993), Giddens (e.g. 1991), Beck and Beck-Gernsheim $(1994,1996)$ and Lash (1994), among many others. Postsocial developments arise from the conjunction of these tendencies. Forms of object-centred relations are presumably not new, and objects, broadly constructed, will surely have been a defining characteristic of other historical periods. On the other hand, it is also plausible to assume that present forms of object-centredness and, if you wish, the recent "object shift," are historically distinct from earlier types of object orientation. For example, a distinctive characteristic of the contemporary situation would appear to be the objects themselves - which, 
we think, are borrowing their characteristics increasingly from the ones present in science and expertise. One important point of this paper will be to show that markets are "epistemic things" - in the sense originally described by Rheinberger (1997) and elaborated by Knorr Cetina (1997).

The idea of postsocial relations as developed here hinges on the notion of an object as an unfolding structure that is non-identical with itself $-\mathrm{a}$ conceptualization that is pertinent to science but stands in contrast to traditional concepts of objects in social science. In addition to conceptualizing objects we will also need to conceptualize sociality; one needs to indicate the mechanism(s) of binding self and other according to which objectual orientations can be seen as social relationships. This will be the second focus of this paper, which will draw on Lacan and his thoughts on the subject as implying a structure of wanting. The interpretation of object-orientations as a postsocial form of relatedness stands in contrast to action-oriented interpretations which encompass such orientations within notions such as work, and instrumental or practical action. One position here is that an object-relations approach does not rule out interpretations along the line of "work" or "action" - and vice versa. In the case of financial markets, the action-oriented approaches can be taken to exemplify questions of the sociology of economics, of industrial sociology and organizational sociology, whereas postsocial object-relations theory relocates the discussion in the framework of transformation theories concerned with the character of the changes now in the making in contemporary life. On the other hand, the present approach also challenges the former perspectives in that it insists on breaking open notions such as "work" or "action." These terms often presuppose but do not unfold the object side in goal-oriented activities and they disregard the relational processes involved. ${ }^{2}$ The notion of postsocial relations with objects rests on the intuition that individuals in some areas relate to (some) objects not only as "doers" and "accomplishers" of things within an agency framework but as experiencing, feeling, reflexive, and remembering beings - as bearers of the sort of experiences we tend to reserve for the sphere of intersubjective relationships.

In what follows we start from a brief sketch of foreign exchange markets developing into the kind of global knowledge object they have become. The sections which follow will present our notion of an object and conceptions of relatedness which we use to fill in what we mean by postsocial relations.

2. Heidegger is often credited with having overcome object-subject distinctions by his insistence that we dwell in a world always already organized in terms of purposes. Yet these ideas were directed against "cognitivist" theories of knowledge that overlooked the directly given and fundamental experience of involvement. They should not rule out analyses of human love as relational processes that presuppose distinctive entities. Heidgger's analysis refers to the fundamental philosophical level of "Dasein" rather than to everyday processes (Heidegger 1962). 


\section{The Market as an Epistemic Thing}

The domain in which we want to test the ideas about postsocial object relations in this paper is that of the foreign exchange market as exemplified by interbank currency trading in large, global investment banks. The data presented in this study derive from participant observation and interviews on the trading floor of a Swiss Bank that has continuously been ranked as one of the top five or seven most profitable banks worldwide by reported foreign exchange trading revenues over recent years (FX Week 1998). ${ }^{3}$ The bank's global presence involved, in 1999, a staff of 14500 working in 60 offices in 30 countries on 6 continents. The foreign exchange market studied has a specific global form, which is not based on the penetration of countries or individual behavior but instead rests on the establishment of bridgehead centers of institutional trading in the financial hubs of the three major time zones: in New York, London, Tokyo, and, since the group to which the investment bank belongs is Swiss, in Zurich. Institutional investors in these regions are linked up with the global bank (henceforth GB1) through "open" or immediate access phone lines. The bank's relevant centres and facilities are also connected through elaborate "intranets" - internal computer linkages that extend across the globe. The intranets include electronic information and brokerage services provided exclusively for institutional customers by firms such as Reuters, Bloomberg and Telerate. Foreign exchange deals through these channels start in the order of several hundred thousand dollars per transaction, and reach up to a hundred million dollars and more. The deals are made by traders, financial managers, fund managers, central bankers, and others who want to avert or hedge against, adverse currency moves, who want to profit from expected currency moves, or who need currencies to help them enter or exit transnational investments.

The activities on trading floors of investment banks have to be distinguished from those observable in most future exchanges, which are set up as "order-markets." In an order market, potential buyers and sellers indicate their intent to brokers, who are the ones standing together in the exchanges' trading pits where they try to find deals for their orders by crying out bids and offers

3. By September 1999, 81 interviews of approximately one and a half hours with traders, salespeople, and analysts on trading floors had been conducted and transcribed. The study is also based on one year of continuous participant observation and, in addition, 10 shorter periods ranging from several days to a week since 1997 and still ongoing. The study is embedded in a larger effort also involving the investigation of analysts in large banks'research departments (see Mars, 1998; Knorr Cetina and Preda, 2000), the analysis of financial documents (see Knorr Cetina, 1999) and the investigation of what we call "global microstructures" (see Bruegger and Knorr Cetina, 2000). 
(these exchanges are aptly called "open outcry" exchanges). In contrast, institutional traders on global investment banks' currency trading floors are "market makers" in so-called "dealer markets." In these markets, which in the case studied involved interbank spot (direct currency exchange) and option trading, dealers trade only with other dealers worldwide for whom they make simultaneous buying and selling offers upon request for indicated amounts of currency pairs (dollars against euros, yen, Swiss francs, etc.). The contacting trader can then trade or not trade, prices are not negotiable within a sequence. Traders also "make prices" (offers to deal) for their own bank's salespersons on the trading floor, who deal with institutional clients such as central banks, pension funds, and corporates. Market makers make money for the bank from speculating on the direction of an exchange rate (from exploiting price differences at different points in time), and from arbitrage (from exploiting price differences between different markets). They also make money from the spread between lower buying and higher selling prices (in stock and bond trading, these correspond to commissions). Trading may also simply have the goal of risk management (e.g. through hedging). As "market makers," traders act as "liquidity providers" for the markets, upholding them by keeping the flow of trades going. Market makers have the "affirmative obligation" (Baker, 1984) to sustain the market (prevent it from breaking down) by offering deals even when the market goes against them and they stand to lose from the deal.

About 200 traders engaged in stock, bond, and currency trading worked on the floor in the Zurich setting. Currency traders sit at "desks" consisting of a row of several (6-12) single desks. They have a range of technology at their disposal, including a "voice broker" (the voice of a broker coming out of an intercom system continuously shouting prices and demanding deals) and a screen-like phone. Most conspicuous, however, are the up to five computer screens confronting each trader, displaying the market and serving to conduct trading. When traders arrive in the morning they strap themselves to their seats, figuratively speaking, they bring up their screens, and from then on their eyes will be glued to that screen, their visual regard captured by it even when they talk or shout to each other, and their body and the screen world melting together in what appears to be a total immersion in the action in which they are taking part. The screens in turn capture the market, which exists only on screen, ${ }^{4}$ where it comes as close as one can get to the ethnomethodological sense of a locally produced phenomenon - if by "local" one means the restriction to a specifiable space. The screens themselves are of course global

4. The market's main medium of existence is the screen. But when there is a prolonged computer failure market makers may revert to the telephone as a way of linking up with customers and of finding out prices. 
rather than local - they are reproduced in identical fashion on the trading floors of the "same tier" banks which are interconnected and "tied together" through phone lines, information technologies which they share, and the same dealing and information systems; participants maintain that a trader flying to Tokyo today can continue trading there tomorrow. The market composes itself in these produced-and-analysed displays to which traders are attached. "It" has in them a distinctive written surface, or, as we shall say later, a gestural facein-action.

What we have said so far can serve as a starting point for the discussion of several characteristics of the market as an object-on-screen in somewhat more detail, paying attention to the epistemic character of this object, its independent existence as a "lifeform," and its gestural face. To begin with the first aspect, in what sense can the market-on-screen be said to be an epistemic object? And what are epistemic objects? Consider first that the market on screen consists of several layers of windows and regions of displays distributed over a number of workstations and computers. The central feature of the displays and the centerpiece of the market for traders are the dealing prices displayed on the "electronic broker." This is a special screen (and machine) that has largely replaced voice broker (real life broker) deals: it displays prices for currency pairs (mainly dollars against other currencies such as the Swiss franc or the euro), deals being possible at these prices. Market makers frequently deal through the electronic broker; the price action there is central to the prices they "make" for callers interested in dealing. Their gaze is also focussed, centrally, on the "Reuters dealing," another special screen (and computer network) through which market makers predominantly make their deals - price and deal requests are made by other parties on these screens through typed messages and deals are concluded in and through "conversations" conducted on screen. These resemble e-mail message exchanges (the Reuters dealing is used for message exchanges in and between dealing conversations) but tend to be much more standardized, in the sense of institutional conversations.

On a different screen traders watch prices put in by different banks worldwide; these prices merely express interest rather than being dealing prices as such. Traders may also watch their own current position in the market (e.g. their being long or short on particular currencies), the history of deals made over recent periods (in spot trading, during a particular day), and their overall account balances (profits and losses over relevant periods) on the work stations at their disposal. Finally, on these screens traders watch items turned out by various news services; these include headline news, commentary and interpretations. An important source of information which also appears on these screens, but is closer to traders' actual dealing in terms of the specificity, speed, and currentness of the information, are internal bulletin boards on 
which participants input information. The screens and windows on the workstations appear piled one upon the other; what is foregrounded depends on the market action and market story. Also, screens are watched with different intensity depending on the importance of their messages - one can imagine them as arranged in concentric circles, with the actual dealing prices and trading conversations always in the center, the indicative prices, account information, and some news (depending on the current market "story") in a second circle, and further headlines and commentaries forming a third layer.

What we have said so far already suggests that the screens present - or appresent, see below - information and knowledge. This is plain with respect to the information on the bulletin board, which displays all of a bank's worldwide traders' and analysts' confidential observations of market players' activities, of political events, and any other events pertinent to dealing and prices. It is also obvious that the entries displayed by news agencies and provider firms such as Reuters and Bloomberg represent information; this is mostly contextual knowledge about economic conditions and items affecting it, but releases also include the important scheduled indicator updates and economic policy statements and changes. What is perhaps less obvious is that the third kind of entry, the centerpiece of what a market is for a trader, the prices, should also be "carriers of knowledge." This is, however, how economists themselves have seen them since the 1940s. In his famous article "The Use of Knowledge in Society" (1945) Hayek argued that the economy consists of "dispersed bits of incomplete and frequently contradictory knowledge which all the separate individuals possess ... knowledge of people, of local conditions, of special circumstances." Hayek's argument was directed against socialist attempts to centralize the economy, and he argued that this knowledge is noncollectible by statistical means (1945: 524) because we do not even know which knowledge we use. It is however, collected in prices: "only the price mechanism can collect and aggregate such knowledge," and the "price system in competitive markets collects information extremely cheaply," taking advantage of the dispersion of knowledge and of decisionmaking (Streissler, 1994: 66-67). When knowledge is thought to be collected "efficiently" we get an efficient market, "one where all new information is quickly understood by market participants and becomes immediately incorporated into market prices" (Samuelson and Nordhaus, 1995: 500f.). Traders rarely share the opinion that the price mechanism is fully efficient, and in fact try to take advantage of information differentials between themselves and less informed market participants. ${ }^{5}$ The point here is that this concerns competition

5. For a documentation of some of these opinions held by analysts see Mars, 1998. 
that is entirely located within the domain of knowledge: it concerns the race for newer knowledge and its incorporation in one's own prices. Prices, then, are knowledge constructs and traders are oriented to them as information in a knowledge game. Finally, knowledge is also implicated in the deals traders make. The prices paid and the deal requests, especially from "smart money (important traders and institutions capable of moving large amounts of money) tell participants where the market might be moving and what is "on its mind." Traders "read the market" through deals, and they also exchange information at the beginning and end of trading sequences and in information conversations.

We have illustrated that the market considered consists of segmented pieces and aggregates of knowledge assembled on screens and orchestrated by traders. In this sense markets-on-screen are knowledge constructs, but they are not yet epistemic objects. The definition of an epistemic object we want to propose owes much to Rheinberger's notion of epistemic things (1992: 310): in essence, Rheinberger applies the term "epistemic thing" to any scientific object of investigation that is at the centre of a research process and in the process of being materially defined. Rheinberger distinguishes these from technological objects, which he considers fixed; they are the stable moments of an experimental arrangement, the unproblematic technical instruments ready-to-hand for investigators. This is a part of the definition we do not share, since technical instruments in many areas, including the present one where instruments are electronic infrastructures and software packages, are also constantly in the process of being (re)fashioned. Objects of knowledge, the ones important in the present context, are characteristically open, questiongenerating, and complex. They are processes and projections rather than definitive things. In our interpretation, objects of knowledge seem to have the capacity to unfold indefinitely; in this sense they lie at the opposite end from pure tools and commercial commodities. These tools and commodities have the character of closed boxes, while objects of knowledge are more like open drawers filled with folders extending indefinitely into the depths of a dark closet. The defining characteristic of this kind of object, from a theoretical point of view, is its lack of "objectivity" and completeness of being, and its non-identity with itself. Since objects of knowledge are always in the process of being materially defined, they continually acquire new properties and change the ones they have.

We can now turn back to markets as these are confronted by traders, and ask whether the characterization just given of knowledge objects applies to them? The answer will be yes; traders are engaged in a process of continually defining the market not only in the sense of trying to read and understand it, but also in the sense or "making" or articulating it, by testing it, moving it, and manipulating it. The market displays itself to them as a complex entity that continually raises new questions, despite the effort which goes into 
collecting and "discounting" the relevant information. Markets are never completely understood, and they acquire new properties as the situation changes and new events (from interest rate changes to the introduction of the euro) unfold. The unfolding structure of the market corresponds to traders' investigative behaviour: to their need to observe and analyse the market at all times of active trading. What the respective epistemic routines consist of is a matter for detailed analysis in its own right which we cannot deal with in this paper. The important point here is that the market is a knowledge object for those who want to participate in it, and in particular for professionals. It might also be noted that the markets explored appear to be epistemic objects in concentrated form - more concentrated than objects of investigation in a benchwork science like molecular biology. These markets are as it were encaged on the screens, held fast there and piling up; they are frequently subject to rapid changes (in currency spot trading sometimes within fractions of a second) and they unfold without regard for working hours and other regulations that locally channel human and institutional constraints.

One might question whether the market should be regarded as an object at all, even if that object is seen as an unfolding structure, and whether it should not rather be disassembled into the human components which lie, perhaps, somewhere behind all market activities. More pointedly, why not consider markets as networks of firms or perhaps of traders as the social structural approach to markets does (see White, 1981; Swedberg, 1994, 1997)? But the markets which interest us here are the ones traders envisage as they sit at their screens and make deals. Traders differentiate between "their networks" of contacts and relationships, which they may consider as a subset of the market, and the market, which, when they are thinking of it in human terms, includes a large component of anonymous behaviour. Markets are objects of observation and analysis because they are not neatly defined within trading environments, they do not have clear borders, and do not reduce to known groups of players engaging in transparent deals. The following quote gives an inclusive definition of the market which brings out the concern with the knowledge of who is doing what, but also with the knowledge of aggregate reported features and the "mind" (Smith 1981) and mood of markets. The territorial disputes between economics, sociology, and psychology over market definitions all melt into a sort of "markets are everything" in which the focus can shift from aspect to aspect:

KK: What is the market for you, is it the price action, or is it individual participants, or - ?

RG: Everything. Everything.

KK: Everything? The information?

RG: Everything. Everything. How loudly he's screaming, how excited he gets, who's selling, who's buying, where, which center, what central banks are doing, what the large funds are doing, what the press is saying, what's happening to the $\mathrm{CDU}$, what the Malaysian prime minister is saying, it's everything - everything all the time. 
The quote comes from an experienced trader who had worked in the Far East and in fact in several countries before coming to Zurich. Note that his "the market is everything" refers precisely to the manifold things that one finds on screens, the news and news commentary, the confidential information about what some major players are doing, and the prices. In the following quote, another equally experienced trader explicitly addresses the character of the market as a "greater being" to which traders are oriented, a being that is sometimes coherent but at other times dispersed and fragmented. This quality as a "greater being" is also what motivates the association in this paper of the market with an (unfolding, never identical) relational object and epistemic thing:

LG: You know it's an invisible hand, the market is always right, it's a lifeform that has being in its own right. You know, in a sort of Gestalt sort of way ( ) it has form and meaning.

KK: It has form and meaning which is independent of you? You can't control it, is that the point?

LG: Right. Exactly, exactly!

KK: Most of the time it's quite dispersed, or does it gel for you?

LG: A-h, that's why I say it has life, it has life in and of itself, you know, sometimes it all comes together, and sometimes it's all just sort of, dispersed, and arbitrary, and random, and directionless and lacking cohesiveness.

KK: But you see it as a third thing? Or do you mean the other person?

LG: As a greater being.

$\mathrm{KK}:$ ( )

LG: No, I don't mean the other person; I mean the being as a whole. And the being is the foreign exchange market - and we are a sum of our parts, or it is a sum of its parts.

KK: I want to come back to the market, what the market is for you. Does it have a particular shape?

LG: No, it changes "shape" all the time.

KK: And what is shape referring to ( ) for you?

LG: Well, the shape is the price action. Like this (pointing at screen) tells me - short term trading. You know, try and buy here, sell here, buy here, sell here, buy here, sell here.

A similar sentiment is expressed when the chief trader on the floor says about trading that it is not a game of "trader against trader but one against the market." Note again that traders also at times consider "the market" in a more restricted and perhaps even more reified way, as when the answer to the question of "where the market is" is a specific price.

\section{The Market as an Object of Attachment: A Postsocial Relationship}

Having said something about the objectuality of markets and their epistemic character as incomplete knowledge constructs we now want to consider notions of sociality that are applicable to the domain investigated. The challenge we face, with the present argument, is to dissociate the notion of a relationship, and of sociality, somewhat from its fixation on human groups. This "loosening up" of the concept of sociality need not start from scratch. 
Mead, among others, discussed communication with non-human objects, and before Mead James and Cooley (McCarthy, 1984; Wiley, 1994: 32ff.). Mead's language of a conversation of gestures allowed him to combine animal and human communication; he also depicted the social act at times as the resultant of a relation between the gesture and accommodating response of two organisms (1934: 80). Markets, of course, are not non-human objects; what brings them nonetheless close to the Meadean concerns with objects and organisms is that they are ungoverned aggregates of anonymous human behaviour and behavioural effects. They also have a strongly expressive, signalling surface to which we will return, using gestural notions, shortly. Generally speaking, sociality is about forms of grouping, binding, and mutuality or reflexivity among humans. What one needs to accomplish in teasing the concept away from its limitation to human groups is to test formulations that focus on the binding mechanism rather than on specific human qualities of individuals. In the following, we will try out a definition of sociality that emphasizes mutuality. Whenever we have mutuality in place, we shall say, we are entitled to use the notion of sociality - provided the engagement is durable and dynamic (and the object is of a particular kind). Note that we do not wish to construe object relationships simply as positive emotional ties, or as being symmetric, non-appropriative, and the like. Social forms include power, negative feelings, and exploitation. We suggest that we can theorize traders' relationships to markets better through a notion of lack, and a corresponding structure of wanting, than through positive ties and fulfilment. The idea of a lack draws on Lacan. To make it clearer we need to return for a moment to our characterization of the market as an object.

We said that the defining characteristic of a market in the present context is its changing, unfolding character; its lack of completeness of being, and its non-identity with itself. The lack of completeness of being is crucial: markets have their moments of fixedness in dealing prices for as long as these hold, but they must simultaneously be conceived as unfolding structures of absences: behind the momentarily fixed facade of prices they have always already begun to mutate, and at times explode, into something else. But this also means that markets are as much defined by what they are not (but might become) as by current states, that they are never quite themselves, and that, as objects of knowledge, they can never be fully attained. What traders encounter on screens are stand-ins for a more basic lack of object. On the subject side, this lack corresponds to a structure of wanting, a continually renewed interest that is never quite fulfilled. The guiding metaphor here is that binding (being-in-relation, mutuality) results from a match between a sequence of wantings and an unfolding object that provides for these wants through the lacks it displays. The wants are never fulfilled but are led on by a continually renewed lack of object. We want to maintain that the open, 
unfolding character of the market-object uniquely matches the structure of wanting by which we can characterize the self.

Let us first explore what a structure of wanting means and recapture the idea in a more sociological framework, and then relate it to the notion of mutuality/reciprocity. The idea of a structure of wanting is derived from Lacan (e.g.1975), but it can also be linked to Baldwin (1973(1899)): 373ff) and Hegel. Lacan derives this wanting not as Freud did from an instinctual impulse whose ultimate goal is a reduction in bodily tension, but from the mirror stage of a young child's development. In this stage the child becomes impressed with the wholeness of his or her image in the mirror and with the appearance of definite boundaries and control - while realizing that he/she is none of these things in actual experience. Wanting or desire is born in envy of the perfection of the image in the mirror or in the mirroring response of the parents; the lack is permanent, since there will always be a distance between the subjective experience of something lacking in our existence and the image in the mirror, or the apparent wholeness of others (Lacan and Wilden, 1968; Alford, 1991: 36ff.).

One can attempt a rendering in a more sociological idiom. The apparent wholeness of others is what the stars and icons of the culture industries project, and the mirror from whose images wanting or desire is born is that of the media which convey their messages mimetically rather than conceptually (Baudrillard, 1983; Lash, 1994: 135ff.). But one can also give a less obvious rendering closer to the present topic. Traders are confronted with the general requirement that they make money for the bank; in fact, they are given precise target values indicating how much they should earn, or in Lacanian idiom, how much they lack. These values are determined once a year on the basis of their previous earnings and the condition of the market. Traders attempt to surpass these goals with a view to a second, more personal goal: that of obtaining an ever higher bonus (whose size depends on their own and the bank's performance) and of accumulating personal wealth. The trading floors of investment banks provide an organized context for giving "lack" a precise institutional and personal meaning that directs unspecific wants to clear goals. The personal and institutional specification of "lack" as a lack of wealth are joined by a number of additional specifications, for example lacks in "character." Trading room culture involves a star system according to which some traders rank far above others in terms of the money they make and the trading skills attributed to them. The star trader in Zurich trades the most important currency pair on the trading floor (dollars against Swiss francs); his daily turnover may be as high as several billion dollars, his daily "P\&L" lies between half a million profit or loss for the bank, and his budget exceeds that of others. His desk is centrally located on the floor, he is in constant communication with the chief trader who sits at a desk next to him, 
and he displays a number of (personalized) characteristics pertinent to his reputation. Some of these are described in the following quote by a colleague:

\begin{abstract}
" $\mathrm{X}$ makes prices all day, he makes the market. He wants to make dollar-Swiss and not dollarmark, since dollar-Swiss is smaller; dollar-mark is too big, no single trader could make the market. X's strength is that he can "bull" his position through. He can tuck his heels in and sit on his balls longest. When others have long quit, he still pushes on. That is his strength."
\end{abstract}

Other traders measure themselves against the performance and behaviour of the "stars" in their business. These traders present "models" of behaviour for the others. As one chief trader said:

\begin{abstract}
"If you have a dollar-Swiss dealer who behaves like a pig you can be sure that within two months everyone behaves like a pig, because he functions like ... a model ... and his behaviour affects the whole dealing room.
\end{abstract}

Because you learn currency trading by watching how someone else does it. You don't learn it from a book, or from an apprenticeship, but on the job. And how do you learn it? By watching how the other person answers the phone, by overhearing how he talks, by seeing how he takes a position."

Traders, then, are made aware of their lacks by their star colleagues on the same trading floor and by the management which calculates what they lack in real money. They are also presented with lacks on a daily basis when they lose money and need to make up their losses, and when they go short on a currency in speculative behaviour. One articulation of lack can be associated with the need, for these traders, to win and not just to do their job in a routine fashion. As Abolafia has emphasized, "the trading floor is not understood as a place to satisfice, footdrag or merely survive, as in other organizational settings. It is a place to win" based on making money (1998: 10). He called the "the sheer raw enjoyment of winning" a secondary goal of excitement and mastery, a goal of "deep play" (Geertz, 1973: 433) beyond the obvious goal of money. If we accept these terms another lack becomes obvious in the cultural constructions of the trader, having to do with a testing of character in a status contest.

One interesting effect of conceiving of this variety in terms of lacks is that it becomes plausible that the lacks need to be managed if the subject is to address them constructively rather than to be overwhelmed by them. This is where the chief trader comes into the picture as a kind of monitor who sees one of his main tasks as building up traders' confidence when the lacks (losses, failures to gain money, being beaten) seem overwhelming, but who also brings them down to earth when they feel like "masters of the universe" after a series of lucky strokes. In that situation, chief traders attempt to puncture dealers' euphoria by putting lids on their risk-taking behaviour and trying to steer them away from high risks (Bruegger, 1999: 282). In the lan- 
guage of lacks, risk-taking means the calculated acceptance of possible future lacks in return for the chance to overcome a lack. Trading, of course, nearly always implies risks. But this means that in this area, future lacks are reflexively built into the very strategies of action adopted to overcome lacks. Traders not only confront lacks, they turn "lacking" into a sophisticated game or practice, a domain of shifting, increasing, decreasing, predicting, hiding, delaying, and trying to live with lack.

Much more would need to be said about the articulation and management of lacks, but we now want to turn back to the object towards which the wants are directed, the market. Our guiding metaphor was that binding (being-inrelation, mutuality) results from a match between a sequence of wantings and an unfolding object that provides for these wants through the lacks it displays. To give substance to this metaphor on the object side we want to reiterate that the object is independent of the subjects' wantings, and that it displays its own lacks. To begin with the first point, consider again participants' conception of the market as a lifeform that they cannot control, even though they are part of it, and may influence prices at times. But they are a very small part of an anonymous mass of exchange behaviour and other effects. As a proprietary trader put it: "(The market) is probably like $99.99999 \%$ anonymous." The market's independence supports the ideas expressed in this paper in that it is an object to which traders relate. It also points to the source of the market's unfolding and "mutation," of its lack of completeness of being and ever new wants - a dispersed mass of participants continues to act, events continue to occur, policies take hold and have effects. The market as an empirical object of ongoing activities and effects continually transforms itself like a bird changing direction in midflight, creating the anticipation problem (the lack of knowledge) traders confront. This lack is exacerbated by the appresentational (Husserl, 1960: 49-54) and representational character of markets-on-screen. The markets investigated display themselves through signifiers which identify the object and render it significant. But these appresentations and representations never quite catch up with the object; in some aspects they always fail and misrepresent the thing they articulate. They regenerate the market in partial and inadequate ways, and give rise to the search processes traders engage in. The market was said to be $99.99999 \%$ anonymous, "because the part that I see, that I can claim I have first-hand knowledge of, is extremely small" (LG 260597 2/1: 9). For this trader, messages like the ones shouted out by salespeople on the trading floor ("(American bank) needs a price in 50 (million dollar) mark-Swiss") were " $100 \%$ transparent" but those on the screens often were not. If a message on the bulletin board said "Bought 50 mark-Swiss for Scandi prop desk" the trader knew the amount and the commodity, but not the price and the Scandinavian buyer. He appreciated the information he got, but this information was nearly always incomplete: "I get 
some information (from the bulletin board and the screens) but not $100 \%$ of the information." Historically, putting markets on screen eliminated a major lack, that of knowing "where the market is" (what the prices are): before they were put on screens, prices differed between places and had to be found out through a painful process of phoning up banks and waiting for lines when going through operators for overseas calls. Contextual information was available only with considerable delays, through papers and the telex, or through the phone conversations. But the screen created new lacks of information in a faster, more liquid and global market. Note that the distinction here is not between an empirical reality of transactions "out there" and their representations on screen. Transactions are performed on screen; as a result, the market exists only on screen - except perhaps for situations of prolonged computer failure when traders might "go back" to older media of transaction. But not all of the ongoing transactions are transparent to everyone; for example, trades may be witnessed by others only within the boundaries of specific commodities, trading floors, or banks (intranets of global banks).

The literal "wants" of the market expressed on screen are the conversationinitiating price questions by other banks and institutions, which traders attempt to "read" with respect to the dealing intentions (buying or selling) of the calling party, for their implied market- (price-) transforming significance, etc., and to which they respond, trying to fulfill their own wants. Note that these literal "wants" are not simple dealing orders yet but messages in need of decoding in a context of market knowledge; they display their own lack of information before they become deal requests. A second layer of lacks indicated on screens concerns the vast area of market knowledge to which traders orient in forming a "view" of the market; the lack refers to the incompleteness of this information just illustrated. The important point here is that the lacks displayed on screen are specific; they suggest what is lacking (in the case illustrated above, the price and the buyer of a commodity), who might have the answer, and which way to look further if necessary through the insufficiencies they display. An important aspect of the notion of a lack as used here is the direct and indirect signifying capacity of the visual and textual signals that indicate a lack. ${ }^{6}$ As a signifying object, the market structures desire, or provides for the continuation of the structure of wanting on the trader's side.

6. This is obvious when lacks are explicit deal requests, but some of the more subtle insufficiencies of information are also suggestive, leading traders to phone up contacts, ask around in the trading room, and fill in the lacking information from their own continuous observation of market behaviour. 
We are now able to spell out more clearly what we mean by a sociality with objects such as markets. Binding, we said, results from the accomplishment of a match between a sequence of wantings and an unfolding object that provides for these wants through the lacks it displays. The core metaphor of sociality here is that of mutuality or reciprocity; combined with a particular conception of objects as an unfolding structure. Sociality occurs when the self as a structure of wanting loops its desire through the object and back. In this movement, the self is endorsed and extended by the object (recall that traders need to prove themselves against the market, to "show character" in it, and so on), which also provides for the continuation of the structure of wanting through its lacks. Sociality here consists in the phenomenon that the subject takes over the object's wants - as a structure of wanting, the subject becomes defined by the object. Conversely, the articulation of the object, the market, is looped through the subject: as a structure of lacks, of the questions it poses and the things that "it" needs, the market receives the kind of extension that the subject determines. In the present case, market continuation literally depends, we said, on market makers' readiness to provide liquidity for the market and to deal, even if they stand to lose money. But the market also becomes substantively defined by the way market makers decide to engage in market continuation.

\section{The Market as an Object of Attachment II: The Meadean Formula}

The formula of a mutual providing by self and object through the interweaving of wants and lacks specifies a kind of backbone of reciprocity for the notion of a postsocial relationship as applicable to markets. It also has room, as we have briefly illustrated in one case, for the accomplished and managed character of the lacks involved. For example, we could easily extend the present analysis to questions such as how the information searches are accomplished, how the looping process is negotiated, and how wants are managed by participants. Most of what is interesting happens during this labor: for example when a trader tries to make sense of market signs to determine what the wants are, and how he or she should therefore structure the next deal or build a view. The Lacanian characterization we have given of postsocial interrelationships has many advantages; it is a convenient way to capture the ways wants have of continually searching out new targets and of moving on to them - a convenient way, if you wish, to capture the volatility and apparent unstoppability of desire. It also brings into view a whole series of moves and their underlying dynamic rather than isolated reasons, as the traditional vocabulary of motives and intentions does. It also suggests a libidinal dimension which appears important in capturing market and knowledge activities. But the characterization given so far can also be based on 
other views of the self's engagement with objects. For example, one can substitute for Lacan's thoughts about the mirror stage Mead's familiar role-taking formula, devised for an interpersonal sociality, which offers a more sociological version of reciprocity as the basis of sociality. Mead's formula entails interpersonal reflexivity coming about through an individual taking the attitude of the other toward him or herself. This attitude then defines and structures the self which is thus socially constituted. The process is mutual and ongoing, and also operates for the daily apprehension of and communication with other people. The formula can easily be applied to market participants who need to "take the perspective of the market," often on a continuous basis.

A first point to consider here is the importance traders attribute to what they call "taking a position," which means opening an account by buying or selling a particular currency against another one with respect to which they will then hold a long (they have bought more than sold), short (they have sold more than they bought) or flat position. What is important for us is that by taking a position, traders say they become part of the market ("if you're taking a position, you are part of the market"). Only then do they develop "an interest in it" and "leap," to use Schutz' language, into it; they switch from being outside to "being in the market." When they are "in the market," traders experience the world from the viewpoint of a market element. As one participant said, "Until you have taken your first position home and tried to go to sleep at night and woken up with a loss staring you in the face, you'll never know if you can make it" (Abolafia, 1998). One can easily maintain that on the level of perspective or viewpoint, position-taking in trading is a rather literal enactment of the sort of role taking Mead envisaged when he talked about taking the position of a generalized or specific other. The market, of course, is a generalized, collective other. Being in the midst of it with a particular currency to sell or buy without loss while trying to make profit is what makes traders observe and imagine the strategies of others, and the collective conditions and effects relevant to their currency pair. It is what encourages them to "sense" and anticipate the market. Traders also talk about how they see things from the point of view of the market:

When I trade I try to find out where the market hurts, what is hurting it ... how is the market positioned. () If I have a long position, () and everyone else is long dollars, and the dollar doesn't want to go any higher, then the dollar will go down. Because if one guy then sells dollars, the other one who buys them doesn't want to keep them, so he also sells. But he already has a lot of dollars that he also wants to sell now. Then there is an erratic, accelerating movement which can only happen when people collectively are on the wrong side. Then I try to imagine what hurts the market, and I try to feel my way into these worst-case scenarios, and to hedge my portfolio accordingly.

We are inclined to summarize this quote in a Meadean idiom by saying that this trader takes the position of the market from the vantage point of his own 
position in it, observing and imagining what others might be doing that creates a "hurting market" (a falling and perhaps failing market), and then acts accordingly. The Meadean formula also contains a reflexive loop: in a personto-person interaction, the other also takes the position of the self, looking at the situation and at himself accordingly. This variety of intersubjectivity also exists with the market, where others will consider a trader's position in it if they have any indication of it, or will try to imagine its contribution to market movements by assimilating it to that of an imagined, generalized other. It might be mentioned that Mead approached the issue as a matter of cognitive reflexivity (Wiley, 1994: 112). Traders, however, often claim they "feel" their way into the market in a more experiential way. This corresponds more to Cooley's notion of the other as an emotional mirror and to a process of imputing sentiments that are "felt" by participants. The following quote by the chief option trader on the trading floor illustrates this feeling for the market (a kind of pattern recognition capacity programmed on long experiene of the market):

You are part of the market, you notice every small shift, you notice when the market becomes insecure, you notice when it becomes nervous, you notice the strong demand ... You notice also that the demand is much greater than the supply. All this (amounts to a) feeling (for the market). When you develop this feeling, and not many people have it, the capacity to feel and sense the market, (etc.).

When someone feels the market, then they can anticipate (it) and can act accordingly. When you are away from the market, and you lack this feeling (for it), then it's incredibly difficult to find it again.

Note that the emotional basis of this sort of intersubjectivity with the market also comes out in traders' vocabulary. As a Zurich trader put it, many of the terms refer "basically (to) sex and violence and a lot of them seem to have to do with anal penetration." The following is a list of examples:

"I got shafted, I got bent over, I got blown up, I got raped, I got stuffed/the guy stuffed me, I got fucked, I got hammered, I got killed."

One interesting facet of this vocabulary is that it displays the assaults implicit in trading as analogous to bodily assaults. Goffman took it to be evident that we could, as he put it, "participate in situations only if we bring our bodies and their accoutrements along with us," and he saw this equipment as vulnerable to physical assault, sexual molestation, etc., by virtue of the instrumentalities that others bring along with their bodies (1983: 4). Traders think of their presence in the markets in terms of "exposures" and "vulnerabilities." Beyond indicating economic danger, the vocabulary displays traders' emotional engagement with the market. Participants appear to be viscerally plugged into the screen reality, they appear bodily there among the other market partici- 
pants conceived as anonymous others. They appear to experience the dangers of intersubjectivity in terms of the penetration of their bodily preserves. One way to make sense of this felt physical connectedness is to return once more to the concrete setup of a trading desk. Through their face and bodyfront traders reorient a significant fraction of their sensory equipment and bodily reaction capabilities to the "lifeform" (native term) of the market - to its glaring and eye-catching presence on screens, its continual vocal demands (phone, voice broker), and its rousing, sometimes galvanizing effects on other traders. We can compare the swiftly changing, flickering screen contents with the expressions of a face, or rather with that of many faces; each screen and subscreen has its own rhythm of change and needs to be decoded in a different way. Clearly the market gives off signs of its states; in the words of the above trader, it may be screaming loudly, it may be very excited, and all this shows. The screens not only capture the markets, they also supply them with a mode of expression. Traders are not able to slip through the screen and walk into this lifeform, but they stand, one might say, within its intimate space close enough to feel every "tick" of its movements, and to tremble and shake whenever it trembles and shakes. Here we can think of a trader's reactions to the market also in terms of Mead's (1934: 144ff.) picture of a conversation of gestures: of reflex-like actions that mirror market movements and respond to them, and that are possible only in a situation of sensory attunement and attachment to a co-present other.

\section{Postsocial Embeddedness}

There is another way to approach sociality, and this is via the notion of embeddedness to which we now want to turn. The meaning embeddedness has in debates between communitarianism and liberalism and more generally in political philosophy, is that of rootedness in and integration with a community to which one belongs (Etzioni, 1993; Sandel, 1982; Walzer, 1990). This idea of embeddedness has been operationalized most concretely in the sociology of economics, which is also relevant to the present concerns. There embeddedness has been conceptualized in reference to actors' economic behaviour as influenced by, and flowing through, the interpersonal and interorganizational ties that structure markets (Granovetter, 1985; see also Portes, 1995: 6, Barber, 1995; DiMaggio, 1994: 24). In accordance with this conception, many authors have understood the market itself in terms of network notions (e.g. White, 1981; Baker, Faulkner and Fisher, 1998: 148ff.; Uzzi, 1997; Fligstein and Mara-Drita,1996: 14f.). The conception has the advantage that it understands embeddedness in its tangible concrete form of ties. But in the present context, it also has the disadvantage of ignoring traders' understandings of the market. To recall, traders depicted the market as "99.99999\% anonymous" and 
as a "greater being" in its own right, as "everything" pertaining to currency exchanges, in particular also as the relevant grid of knowledge, and as price action. These notions can hardly be summarized adequately by the concept of a network or a community formed by social relations.

Consider once more what we need to accomplish. First, when we turn to the idea of embeddedness we are also turning to a more collective level of sociality and relatedness than hitherto considered. Second, we need to come up with an understanding of this collective level that is not based on human relationships, exclusively. The question to ask is whether the idea of embeddedness can be extended to global domains whose participants are not, as in traditional communities, in one another's physical response presence and represent anonymous aggregates. We want to submit that temporal mechanisms, and the common orientation of participants to an object on screen, may constitute a basis for a postsocial form of "intersubjectivity" and integration that manifests itself on this level. We will discuss this by drawing on Schutz and his ideas about temporal synchronization.

Schutz associated his theory of intersubjectivity closely with the bodily presence of participants in the same situation, but he also arrived at another idea which became central to his conception, that of temporal coordination. As one of his followers put it, "The reciprocal interlocking of time dimension is for Schutz the core phenomenon of intersubjectivity" (Zaner, 1964). As much as the "spatial immediacy" of embodied encounters, Schutz noted the "temporal immediacy" that obtains in this situation. He contended that this temporal immediacy allowed one to recognize and follow another person's experience (say of a bird in flight) as contemporaneous with one's own experience. Schutz tried his hand at a number of formulations of the temporal coordination of "phases of consciousness"; he spoke of the "synchronization of two interior streams of duration" and of the fact that during this synchronization, "we are growing older together" (1964, vol. II: 24-26).

The point for us is that in emphasizing temporal coordination, Schutz moved away from any attempt to base social relatedness on the idea of shared (in the sense of identical) experience or on any real understanding of other minds. Instead, he left things with the subject recognizing the other as a fellow human being here and now, evidently paying attention to the same event. What turned this experience into a "We-relation," as he called it, was the contemporaneousness of an event, one's experiencing it, and the indications of the other's attentiveness to it: "Since we are growing older together during the flight of the bird, and since I have evidence, in my own observations, that you were paying attention to the same event, I may say that we saw a bird in flight" (1964, vol. II: 25$)$.

To illustrate this now in regard to financial markets we can start with the question of what the "same events" might be that could plausibly be construed 
as globally observed in the same binding fashion in which events are observed in the face-to-face situation. These events are delivered, we want to argue, by the knowledge-created phenomena on screen and the content of the supplemental channels to which traders are oriented. In other words, the bird that traders watch together around the clock is "the market," as it is assembled in identical (price actions, market analyses, news descriptions etc. furnished by global information providers), overlapping (information exchanged through personal relationships), and coordinated fashion in the many windows and channels to which participants are attached. In these windows and channels the "same" market has a vivid presence; it speaks out to participants and demands from these connected continuous attention - and action.

Consider now a second feature on which Schutz based the We-relation, that of temporal coordination (see also Zerubiavel, 1981). First, traders, salespeople, and others on trading floors located within a particular time zone share a community of time. They watch the market as it comes into view in the morning and builds up during the day virtually continuously in synchronicity and immediacy during their working (and waking) hours. ${ }^{7}$ All three aspects are important here: synchronicity refers to the phenomenon that traders and salespeople observe the same market events simultaneously over the same time period; continuity means they observe the market virtually without interruption, having lunch at their desk and asking others to watch when they step out; and temporal immediacy refers to the immediate real time availability of market transactions and information to participants within the appropriate institutional trading networks. Local news is also transmitted on screen "live" when the events are scheduled at a particular time (e.g. announcements of economic indicators), or it is transmitted with as little delay as possible. Traders, investors, and others attempt to gain advance knowledge of special developments, but these pursuits presuppose rather than undercut the community of time which obtains with respect to the market.

7. As Harvey has argued (1989: 239-59), increasing time-compression is a characteristic of the whole process of modernity and of post-industrialization. A similar argument had been advanced by McLuhan (1964: 358), who proposed that electricity establishes a global network of communication that enables us to apprehend and experience media-transmitted events nearly simultaneously, as in a common central nervous system (see also Waters, 1995: 35; Giddens, 1990: 17-21). These views anticipate global integration by means of a common (media) culture or consciousness rather than by means of economics, in contrast to other approaches (Waters, 1995: 33-35; Wallerstein, 1974, 1980). Yet what we are after here is something much less general in scope (most of the world is excluded from traders' screen world) and more micro-level in character: a form of time coordination that penetrates all of the participants' interactions and involves dozens of small mechanisms of binding participants into the same time frame. 
Time coordination also involves, second, a temporal division of labour across time zones, to the effect that the community of time extends around the clock. As an example take the trading instrument of an "option" to buy or sell a currency at a particular point in the future, at an agreed price. In contrast to the instantaneously completed on the "spot" sales and purchases of currencies discussed so far, options expire weeks or months after the deal was made; hence unlike a spot trader's accounts, an option trader's accounts cannot be closed every night. One way to organize such long-term transactions globally is to pass on a desk's option accounts every evening to the same bank's option traders in the next time zone, who will manage the accounts and add deals during their working hours. The "option book" that circles the globe indicates global financial integration: one extends the surveillance of the "bird in flight," the market, through the eyes of others, when it threatens to disappear from view during the night. The circling book can be seen as an attempt to weave together the market through the participation of those attending to it and buying into it in different time zones, with the effect of creating an around-the-clock synchronization of observation and experience.

A third aspect of time coordination beyond this attempted global contemporaneity brings into view market "calendars" and schedules: dates and hours set for important economic announcements and for the release of periodically calculated economic indicators and data. These calendars and schedules structure and pace participants' awareness and anticipation. They create an atmosphere of collective anticipation and preparation for specific events that pace and interrupt the regular flow of market activities. Temporal structures of this sort recurrently focus a global field of watchers on possible changes of direction of the "bird in flight." They bind the field to specific time frames around which global attention is heightened and in relation to which expectations build up. The ordinary temporal flow of synchronous and sequential time-zone observation is thus punctuated regularly by potentially trend-changing occurrences. The scheduled character of these events not only synchronizes experience on a collective and global level, but adds to it a measure of emotional arousal. ${ }^{8}$ Durkheim thought such arousals to be central to bringing about a feeling of "solidarity": he assumed that the We-experience arises when a group becomes excited (e.g. Wiley, 1994: 106, 122).

To conclude this section and the paper, consider that the notion of a postsocial form when applied to relationships with objects has two prerequisites. The first prerequisite is that one needs to specify the object in this approach. We have provided a definition of market objectuality that builds on the notion

8. For an interesting historical example of the use of schedules see Zerubiavel, 1981: $\operatorname{ch} 2,65 \mathrm{ff}$. 
of a lack and also brings in the market as a knowledge project. The second prerequisite is that one needs to indicate the mechanism that binds self and other, and accounts for the continued and repeated attraction between the two units. We have "tested" three varieties of understanding postsocial relatedness: one based on Lacan, one on Mead, and one on Schutz. With Schutz we have gone beyond the forms of attachment addressed in detail in this paper, in an attempt to make clear that postsocial forms can also be located on a more collective level of sociality; Schutz' ideas provide a starting point for the further analysis of such collective forms, which will have to be pursued in future work. Integration in the social sciences is almost universally understood in terms of human bonds formed through common interests (e.g. as when embeddedness refers to networks of relationships) or through normative consensus and shared values (as in the tradition of Parsons and Durkheim). But these forms of integration appear to become less and less effective given the increased cultural and other diversity of the respective populations, increased detraditionalization, and the "waning" of social authorities that symbolize value integration. In fact, as Etzioni has pointed out (1993), normative integration may be imaginable today only as a socioculturally engineered consensus. Peters (1993) has argued that integration may also arise from other factors, for example from the joint prosperity which binds large segments of the population into society. Joint prosperity significantly involves objects, whose role in relation to integration may need to be spelled out. In this paper, we have attempted to conceive of the market as an object that binds anonymous masses of people together by focussing their attention on specific events in temporal synchronicity. In this sense, the market can be seen not only as an object of attachment but also as an embedding environment for the self.

\section{References}

Abolafia, Mitchel Y.

1996 Making Markets: Opportunism and Restraint on Wall Street. Cambridge, MA: Harvard University Press.

1998 "Opportunism and Hyper-Rationality: The Social Construction of Economic Man on Wall Street". Unpublished manuscript.

Alford, C. Fred

1991 The Self in Social Theory. New Haven: Yale University Press.

Baker, Wayne E.

1984 "The Social Structure of a National Securities Market." American Journal of Sociology 89(4): 775-811.

Baker, Wayne E., Robert R. Faulker and Gene A. Fisher

1998 "Hazards of the Market: The Continuity and Dissolution of Interorganizational Market Relationships." American Sociological Review 63: 147-177. 
Baldwin, James M.

1973 (1899)

Social and Ethical Interpretations of Mental Development. New York: Arno Press.

Barber, Bernard

1995 "All Economies Are 'Embedded': The Career of a Concept and Beyond." Social Research 62: 387-413.

Baudrillard, Jean

1983 Simulations. New York: Semiotext(e).

1996 The System of Objects. London: Verso.

Beck, Ulrich and Elisabeth Beck-Gernsheim

1994 The Normal Chaos of Love. Cambridge: Polity.

1996 "Individualization and 'Precarious Freedoms': Perspectives and Controversies of a Subject-Oriented Sociology." In Paul Heelas, Scott Lash and Paul Morris (editors), Detraditionalization: Critical Reflections on Authority and Identity. Oxford: Blackwell.

Bruegger, Urs

1999 Wie handeln Händler? Akteure der Globalisierung. Unpublished PhD Dissertation, University of St. Gallen, Switzerland.

Bruegger, Urs and Karin Knorr Cetina

2000 "Global Microstructures: The Interaction Practices of Financial Markets." American Journal of Sociology (forthcoming).

Coleman, James

1993 "The Rational Reconstruction of Society: 1992 Presidential Address." American Sociological Review 58: 1-15.

DiMaggio, Paul

1994 "Culture and the Economy." In N. Smelser and R. Swedberg, eds., The Handbook of Economic Sociology. Princeton: Princeton University Press.

Etzioni, Amitai

1993 The Spirit of Community: Rights, Responsibilities, and the Communitarian Agenda. New York: Simon and Schuster.

Falk, Pasi and Colin Campbell

1997 The Shopping Experience. London: Sage.

Fligstein, Neil and Iona Mara-Drita

1996 "How to Make a Market: Reflections on the Attempt to Create a Single Market in the European Union." American Journal of Sociology 102(1): 1-33.

FX Week

1998 June 1, Vol. 9, No 22.

Geertz, Clifford

1973 The Interpretation of Cultures. New York: Basic Books.

Giddens, Anthony

1990 The Consequences of Modernity. Stanford: Stanford University Press.

1991 Modernity and Self-Identity. Cambridge: Polity.

Goffman, Erving

1983 "The Interaction Order." American Sociological Review 48: 1-17.

Granovetter, Mark

1985 "Economic Action and Social Structure: The Problem of Embeddedness." American Journal of Sociology 91(3): 481-510. 
Harvey, David

1989 The Condition of Postmodernity: An Inquiry into the Origins of Cultural Change. New York: Blackwell.

Hayek, Friedrich A.

1945 (1976)

"The Use of the Knowledge in Society." In F.A. Hayek, Individualism and Economic Order. London Routledge \& Kegan Paul

Heidegger, Martin

1962 (1927)

Being and Time. New York: Harper \& Row.

Heim, Michael

1993 The Metaphysics of Virtual Reality. Oxford: Oxford University Press.

Husserl, Edmund

1960 Cartesian Mediations. (English translation by D. Cairns). The Hague: Nijhoff.

Knorr Cetina, Karin

1997 "Sociality with Objects. Social Relations in Postsocial Knowledge Societies." Theory, Culture \& Society 14(4): 1-30.

1999 "Financial Markets and the Cultural Production of Transparency." Paper presented at the Annual Meeting of the American Sociological Association, Chicago, August 6-10, 1999.

Knorr Cetina, Karin and Alexandru Preda

2000 "Postsocial Knowledge Societies: The Epistemic Embeddedness of Economic Action." In Karl S. Althaler, Marco Lehmann-Waffenschmidt and Karl H. Müller (editors), The Socio-Economics of Long-Term Evolution. Advances in Theory, Complex Modeling, and Methodology. Berlin: Fakultas Verlag (forthcoming).

Lacan, Jacques

1975 The Language of the Self. New York: Dell.

Lacan, Jacques. and Anthony Wilden

1968 Speech and Language in Psychoanalysis. Baltimore: Johns Hopkins University Press.

Lasch, Christopher

1978 The Culture of Narcissism. New York: Norton.

Lash, Scott

1994 "Reflexivity and its Doubles: Structure, Aesthetics, Community." In U. Beck, A.

Giddens and S. Lash, Reflexive Modernization. Stanford, CA: Stanford University Press.

Lyng, Stephen

1990 "Edgework: A Social Psychological Analysis of Voluntary Risk Taking." American Journal of Sociology 95(4): 851-86.

Mars, Frank

1998 "Wir sind alle Seher. Die Praxis der Aktienanalyse." Unpublished dissertation. Faculty of Sociology, University of Bielefeld.

McCarthy, E. Doyle

1984 "Toward a Sociology of the Physical World: George Herbert Mead on Physical Objects." Studies in Symbolic Interaction 5: 105-21.

McLuhan, Marshall

1964 Understanding Media. London: Routledge.

Mead, George H.

1934 Mind, Self and Society. Chicago: University of Chicago Press. 
Miller, Daniel

1994 Modernity - An Ethnographic Approach. Oxford: Berg.

Peters, Bernhard

1993 Die Integration moderner Gesellschaften. Frankfurt/M.: Suhrkamp.

Portes, Alejandro

1995 "Economic Sociology and the Sociology of Immigration: A Conceptual Overview." In A. Portes (editor), The Economic Sociology of Immigration. New York: Russell Sage Foundation.

Rheinberger, Hans-Jörg

1992 "Experiment, Difference, and Writing: I. Tracing Protein Synthesis," Studies in the History and Philosophy of Science 23(2): 305-31.

1997 Toward a History of Epistemic Things. Stanford: Stanford University Press.

Ritzer, George

1999 Enchanting a Disenchanted World. Thousand Oaks: Pine Forge Press.

Samuelson, Paul A. and William D. Nordhaus

1995 Economics. New York: McGraw-Hill.

Sandel, Michael J.

1982 Liberalism and the Limits of Justice. Cambridge, MA: Cambridge University Press.

Schutz, Alfred

1964 Collected Papers II: Studies in Social Theory. Edited and introduced by Arvid Broodersen. The Hague: Nijhoff.

1967 The Phenomenology of the Social World. Evanston, ILL: Northwestern University Press.

Serres, Michel

1990 Le Contrat Naturel. Paris: Editions Francois.

Sheldrake, Rupert

1991 The Rebirth of Nature. London: Rider.

Smith, Charles W.

1981 The Mind of the Market. London: Croom Helm.

Stone, Allucquere R.

1996 The War of Desire and Technology at the Close of the Mechanical Age. Boston: MIT Press.

Streissler, Erich W.

1994 "Hayek on Information and Socialism." In Marco Colonna, Harald Hagemann and Omar Hamouda (editors), The Economics of F.A. Hayek. Vo. 2. Aldershot: Elgar.

Swedberg, Richard

1994 "Markets as Social Structures." In N. Smelser and R. Swedberg (editors), The Handbook of Economic Sociology. Princeton: Princeton University Press.

$\rightarrow 1997$ "New Economic Sociology: What Has Been Accomplished, What Is Ahead?" Acta Sociologica 40: 161-182.

Turkle, Sherry

1995 Life on the Screen. New York: Simon and Schuster.

Uzzi, Brian

1997 "Social Structure and Competition in Interfirm Networks: The Paradox of Embeddedness." Administrative Science Quarterly 42: 35-67.

Wallerstein, Immanuel

1974 The Modern World System. New York: Academic Press.

1980 The Capitalist World-Economy: Essays. Cambridge: Cambridge University Press. 
Walzer, Michael

1990 "The Communitarian Critique of Liberalism." Political Theory 18(1): 6-23.

Waters, Malcolm

1995 Globalization. London: Routledge.

$\rightarrow$ White, Harrison

1981 “Where Do Markets Come From?” American Journal of Sociology 87: 517-47.

Wiley, Norbert

1994 The Semiotic Self. Chicago: University of Chicago Press.

Zaner, Richard

1964 The Problem of Embodiment: Some Contributions to a Phenomenology of the Body. The Hague: Nijhoff.

Zerubiavel, Eviatar

1981 Hidden Rhythms. Schedules and Calendars in Social Life. Berkeley, CA: University of California Press. 